American Journal of Infectious Diseases 5 (2): 60-67, 2009

ISSN 1553-6203

(C) 2009 Science Publications

\title{
In vitro and In vivo Antioxidant Activity of Aphanamixis polystachya Bark
}

\author{
Alluri V. Krishnaraju, Chirravuri V. Rao, Tayi V.N. Rao, K.N. Reddy and Golakoti Trimurtulu \\ Laila Impex R and D Centre, Unit-I, Phase-III, Jawahar Autonagar \\ Vijayawada-520007, India
}

\begin{abstract}
Problem statement: Free radical stress leads to tissue injury and progression of disease conditions such as arthritis, hemorrhagic shock, atherosclerosis, diabetes, hepatic injury, aging and ischemia, reperfusion injury of many tissues, gastritis, tumor promotion, neurodegenerative diseases and carcinogenesis. Safer antioxidants suitable for long term use are needed to prevent or stop the progression of free radical mediated disorders. Approach: Many plants possess antioxidant ingredients that provided efficacy by additive or synergistic activities. A. polystachya bark was a strong astringent, used for the treatment of liver and spleen diseases, rheumatism and tumors. Antioxidant activity of the crude extracts of bark of $A$. polystachya were assessed using NBT, DPPH, ABTS and FRAP assays. The potent fraction (AP-110/82C) was tested for in vivo efficacy Results: The methanol, aqueous methanol and water extracts exhibited potent antioxidant activity compared to known antioxidants. In vivo studies on potent fraction AP-110/82C demonstrated dose dependent reduction in hepatic malondialdehyde (320.6, 269.3 and $373.69 \mu \mathrm{M} \mathrm{mg}^{-1}$ protein) with simultaneous improvement in hepatic glutathione $\left(6.9,17.1\right.$ and $5.8 \mu \mathrm{g} \mathrm{mg}^{-1}$ protein) and catalase levels $(668.9,777.0$ and $511.94 \mu \mathrm{g} \mathrm{mg}^{-1}$ protein) respectively for $50,100 \mathrm{mg} \mathrm{kg}^{-1}$ doses and control) compared to control group. Conclusion: Due to its natural origin and potent free-radical scavenging ability A. polystachya could be used as a potential preventive intervention for free radical-mediated diseases.
\end{abstract}

Key words: Aphanamixis polystachya, antioxidant, MDA, glutathione, catalase

\section{INTRODUCTION}

A common theme which underlies etiology of several degenerative disorders is free radical stress. The production of free radicals is inextricably linked to the inflammatory process. Free radicals prime the immune response, recruit inflammatory cells and are innately bactericidal $^{[1,2]}$.

Some of these free radicals play a positive role in vivo such as energy production, phagocytosis, regulation of cell growth and intercellular signaling, or synthesis of biologically important compounds ${ }^{[3]}$. However, free radicals are very detrimental in attacking lipids in cell membranes and also DNA, inducing oxidations that cause membrane damage such as membrane lipid peroxidation and a decrease in membrane fluidity and also cause DNA mutation leading to cancer ${ }^{[4,5]}$. Free radicals and oxidants activate nuclear factor- $\mathrm{\kappa B}$, a nuclear transcription factor, resulting in an upregulation of pro-inflammatory mediators such as interleukin-1, interleukin-8 and tumor necrosis factor- $\alpha^{[2]}$. This in turn stimulates the immune response, increases oxidant production and can lead to further tissue damage.
A potent scavenger of these free radical species may serve as a possible preventive intervention for free radical mediated diseases ${ }^{[6]}$. Recent studies showed that a number of plant products including polyphenolic substances (e.g., flavonoids and tannins) and various plant or herb extracts exert potent antioxidant actions $^{[7-9]}$. Aphanamixis polystachya also known as Amoora rohituka is a valuable medicinal plant of meliaceae family which is abundantly found in India. A. polystachya bark is a strong astringent, antimicrobial, used for the treatment of liver and spleen diseases, rheumatism and tumors ${ }^{[10-12]}$. A number of limionoids, triterpenes, sesquiterpenes alkaloids and flavonoid glycosides were isolated from A. polystachya. Limonoids ${ }^{[13,14]}$ isolated from the seeds and bark, flavonoid glycosides and a chromone ${ }^{[15]}$ isolated from roots, triterpenes ${ }^{[16]}$, guanine sesquiterpenes ${ }^{[17]}$ isolated from stem bark and alkaloid rohitukine ${ }^{[18]}$ isolated from stems and leaves are a key metabolites in A. polystachya. A. polystachya bark extacts showed antitumor activity ${ }^{[19]}$ radioprotective efficacy $^{[20]}$ and augment the frequency of defecation and propulsion of the GI content ${ }^{[21]}$. A. polystachya Corresponding Author: Alluri V. Krishnaraju, Laila Impex R and D Centre, Unit-I, Phase-III, Jawahar Autonagar, Vijayawada-520007, India 
seed exacts showed antifeedant, repellant and contact toxicity to betels ${ }^{[22]}$.

The objective of this study is to find antioxidant activities of A. polystachya bark extracts and fractions using various in vitro and in vivo models for example, measuring free radical scavenging activity by NBT (Nitro blue tetrazolium), DPPH (2, 2-diphenyl-1picrylhydrazyl), ABTS $[2,2$ azino-bis (3ethylbenzothiazoline-6-sulphonic acid) diammonium salt] and FRAP [Ferric reducing antioxidant power] assays and estimation of liver Glutathione and malondialdehyde levels of rats supplemented with AP$110 / 82 \mathrm{C}$.

\section{MATERIALS AND METHODS}

The plant material (bark of Aphanamixis polystachya) was collected from Maredumilli reserve forest Rampachodavaram range, (Nort-Eastern Ghats) of Andhra Pradesh, in September 2006 and identified by Dr. K. Narasimha Reddy. Voucher specimen (No. LIH6187) was deposited in the raw drug specimen depository of the Taxonomy Division at Laila Impex R \& D Centre, Vijayawada, India.

Powdered material (700 g) of A. polystachya bark, was successively extracted with hexane $(2 \mathrm{~L})$, ethyl acetate $(1.75 \mathrm{~L})$ and methanol $(1.75 \mathrm{~L})$ using a Soxhlet apparatus and the spent material was then extracted with aqueous methanol $(80 \%, 1.75 \mathrm{~L})$ followed by water $(1.75 \mathrm{~L})$. The extracts were filtered and concentrated independently and dried under reduced pressure to obtain, hexane $(17.0 \mathrm{~g})$, ethyl acetate $(3.9 \mathrm{~g})$, methanol $(72.0 \mathrm{~g})$, aqueous methanol $(20.0 \mathrm{~g})$ and water $(29.9 \mathrm{~g})$ extracts. These extracts were used as test substances. A Potent antioxidant fraction obtained through bioactivity guided fractionation was used for in vivo efficacy studies. Blend of methanol and aqueous methanol extract of A. polystachya bark was further fractionated in to acetone soluble and the acetone insoluble fractions. The latter (AP 110/82C) which showed potent free radical scavenging activity was used for in vivo evaluation.

Reagents and chemicals: Nitro blue tetrazolium, Riboflavin, Metaphosphoric acid and all the solvents used in the study were of analytical grade and were procured from S D Fine Chemicals Limited, Mumbai, India. 1, 1-diphenyl-2-picrylhydrazyl, 2, 2'-azino-bis(3-ethylbenzothiazoline-6-sulfonic acid), Vitamin C, thiobarbituric acid, malondialdehyde and other chemicals were obtained from Sigma Chemical Company (St. Lousis, MO).
In vitro Antioxidant activity:

Superoxide free-radical scavenging activity: Superoxide radical scavenging activity of various extracts of A. polystachya was determined by Nitro Blue Tetrazolium (NBT) riboflavin photo reduction method of McCord and Fridovich ${ }^{[23]}$. The assay mixture contained EDTA solution $(6.6 \mathrm{mM})$ containing $\mathrm{NaCN}$ $(3 \mu \mathrm{g})$, riboflavin $(2 \mu \mathrm{M})$, NBT $(50 \mu \mathrm{M})$, test substances and phosphate buffer $(67 \mathrm{mM}, \mathrm{pH} 7.8)$ in a final volume of $3 \mathrm{~mL}$. The absorbance at $560 \mathrm{~nm}$ were measured before and $15 \mathrm{~min}$ after illumination. All tests were run in triplicate and mean values were used to calculate percentage scavenging ability and $\mathrm{IC}_{50}$ values were calculated using linear regression analysis.

DPPH free-radical scavenging activity: DPPH $(1,1-$ diphenyl-2-picrylhydrazyl) radical-scavenging activity was measured by the method of Szabo et al. ${ }^{[24]}$ The reaction mixture contained $1.5 \times 10^{-7} \mathrm{M}$ methanolic solution of DPPH and various concentrations of the test substances and were kept in dark for $50 \mathrm{~min}$. Optical Density (OD) of the samples was measured at $517 \mathrm{~nm}$ against a blank and $\mathrm{IC}_{50}$ values were calculated using linear regression analysis.

ABTS free-radical scavenging activity: The ABTS assay of Roberta et al. ${ }^{[25]}$ was employed to measure the antioxidant activity of $A$. polystachya extracts. ABTS was dissolved in distilled water to $7 \mathrm{mM}$ concentration and potassium persulphate added to a concentration of $2.45 \mathrm{mM}$. The reaction mixture was left to stand at room temperature overnight (12-16 h) in dark before usage. The resultant intensely-coloured $\mathrm{ABTS}^{+}$radical cation was diluted with ethanol to give an absorbance value of $\sim 0.70$ at $734 \mathrm{~nm}$. Various concentrations of test substances were incubated with the $\mathrm{ABTS}^{\circ+}$ solution for $30 \mathrm{~min}$ and OD was measured at $734 \mathrm{~nm}$ against a blank and $\mathrm{IC}_{50}$ values were calculated using linear regression analysis.

FRAP assay: The Ferric Reducing Antioxidant Power (FRAP) of various extracts of A. polystachya was performed based on the method of Benzie and Strain ${ }^{[26]}$. The assay mixture contained $2.5 \mathrm{~mL}$ of $300 \mathrm{mM}$ acetate buffer at $\mathrm{pH} 3.6,0.25 \mathrm{~mL}$ of $10 \mathrm{mM}$ TPTZ solution in $40 \mathrm{mM} \mathrm{HCl}, 0.25 \mathrm{~mL}$ of $20 \mathrm{mM} \mathrm{FeCl}{ }_{3}$ and test substances in $0.1 \mathrm{~mL}$ water or methanol. The absorbance was measured after $30 \mathrm{~min}$ incubation at $593 \mathrm{~nm}$. Standard graphs were constructed using known concentrations of ferrous salt in water/methanol to replace $\mathrm{FeCl}_{3}$. All tests were run in triplicate and mean values were used to calculate $\mathrm{EC}_{1}$ values. $\mathrm{EC}_{1}$ is defined as concentration of an antioxidant having a ferric reducing ability equivalent to that of $1 \mathrm{mM}$ ferrous salt. 
In vivo Antioxidant activity:

Animal procedure: Male and Female SD rats obtained from NIN, Hyderabad, after quarantine and acclimatization were randomly divided into four groups, each containing 6 animals. Selected rats were housed individually in polypropylene cages with stainless steel grill floors and fed with Nutrilab standard rodent diet. This study protocol (LI 061006A) was approved by Institutional Animal Ethics Committee (IAEC) of Laila Impex $\mathrm{R}$ and $\mathrm{D}$ Centre. The animal room was maintained at a controlled temperature (20$\left.24^{\circ} \mathrm{C}\right)$, humidity $(45-70 \%)$ and light $\left(12 \mathrm{~h}\right.$ light $12 \mathrm{~h}^{-1}$ dark). The treatment group of rats were supplemented with 50 or $100 \mathrm{mg} \mathrm{kg}^{-1}$ of AP-110/82C or $10 \mathrm{mg} \mathrm{kg}^{-1}$ prednisolone (positive control) for 4 weeks. The control group animals received same volume of $1 \% \mathrm{CMC}$. At the 14th day, oxidative stress was induced in the animals by administering Freund's Complete Adjuvant. The animals were sacrificed on 28th day. The liver tissue samples were collected and analyzed for antioxidant status by measuring tissue malondialdehye and glutathione concentrations.

Assay of malondialdehyde (MDA): Lipid peroxidation was estimated in terms of Thiobarbituric ${ }^{[27]}$ Acid Reactive Species (TBARS), using Malondialdehyde (MDA) as standard. The homogenized liver tissue $(400 \mu \mathrm{l})$ was mixed with $10 \%$ TCA and incubated for $15 \mathrm{~min}$ at $4^{\circ} \mathrm{C}$ and then centrifuged at $2,200 \mathrm{~g}$ for $15 \mathrm{~min}$ at $4^{\circ} \mathrm{C}$. To $1 \mathrm{~mL}$ of protein-free supernatant, $1 \mathrm{~mL}$ of fresh TBA reagent was added, mixed thoroughly and incubated at $60^{\circ} \mathrm{C}$ for $1 \mathrm{~h}$ in water bath. Then optical density was measured at $532 \mathrm{~nm}$ for the assay of MDA. Lipid peroxide is expressed in terms of $\mathrm{nM}$ of MDA mg ${ }^{-1}$ of liver tissue.

Assay of total tissue sulfhydryl group (reduced glutathione level): The soluble sulphydryl content of liver was determined according to the method of Grunert and Phillips ${ }^{[28]}$. The metaphosphoric acid extract of liver or fractions, was saturated with $\mathrm{NaCl}$ and allowed to stand for 15-30 min and centrifuged at $3000 \mathrm{rpm}$ for $10 \mathrm{~min}$ at $4^{\circ} \mathrm{C}$. Take $1 \mathrm{~mL}$ of the aliquot of the supernatant and add to $3 \mathrm{~mL}$ saturated $\mathrm{NaCl}$ solution, allow it to stand for $10 \mathrm{~min}$ at $25^{\circ} \mathrm{C}$. The nonspecific absorption in the sample was eliminated by reading the sample against a blank containing $2 \%$ metaphosphoric acid and Sodium nitroprusside. The colored complex developed is measured immediately at $520 \mathrm{~nm}$ on a colorimeter using blank tube.

Catalase assay: Catalase (CAT) activity was measured by monitoring decomposition of $\mathrm{H}_{2} \mathrm{O}_{2}$ according to the method of Johansson and Borg ${ }^{[29]}$. The reaction was initiated by adding $50 \mu \mathrm{L}$ of homogenized liver sample to the reaction mixture containing $250 \mathrm{mM}$ PBS with $12 \mathrm{M}$ methanol and $44 \mathrm{mM} \mathrm{H} \mathrm{O}_{2}$ and incubated at room temperature for $20 \mathrm{~min}$. The reaction was terminated with addition of Purpald $(22.8 \mathrm{mM})$ and again incubated at room temperature for $20 \mathrm{~min}$. After adding potassium periodate $(65.2 \mathrm{mM})$, the absorbance of the sample was measured at $550 \mathrm{~nm}$. Catalse concentration was estimated by a standard graph plotted using known concentrations of formaldehyde and results expressed IU $\mathrm{mg}^{-1}$ protein.

Statistical analyses: Statistical analyses were carried out using GraphPad Instat. Differences among the tested antioxidants were analyzed by using one-way ANOVA. Values are expressed as the mean \pm SEM and differences between groups were considered to be significant if $\mathrm{p}<0.05$.

\section{RESULTS}

In Vitro Antioxidant activity:

Superoxide free radical scavenging activity: The Superoxide radical scavenging activity of A. polystachya bark extracts was studied in compared with vitamin $\mathrm{C}$. The methanol, aqueous and aqueous methanol extracts showed potent superoxide radical scavenging activity, as indicated by their $\mathrm{IC}_{50}$ values 7 , 7 and $8.3 \mu \mathrm{g} \mathrm{mL}^{-1}$ respectively compared to Vitamin $\mathrm{C}$ which showed an $\mathrm{IC}_{50} 125 \mu \mathrm{g} \mathrm{mL}^{-1}$. From a comparison of $\mathrm{IC}_{50}$ values $A$. polystachya extracts were found to be about 16 times more potent than that of vitamin C. The results were shown in Fig. 1.

DPPH free radical scavenging activity: The results of the DPPH scavenging activity of $A$. polystachya bark extracts are shown in Fig. 2. The scavenging ability of methanol, aqueous methanol and water extracts was comparable to Vitamin $\mathrm{C}$, however ethyl acetate and hexane extracts did not exhibited significant DPPH scavenging efficacy.

ABTS free radical scavenging activity: It is palpable from Fig. 3 that the A. polystachya bark extracts exhibited potent ABTS free radical scavenging activity compared to that vitamin $\mathrm{C}$. The $\mathrm{IC}_{50}$ value indicated that the ABTS free radical scavenging activity of $A$. polystachya extracs was nearly 2 fold higher than vitamin $\mathrm{C}$. The $\mathrm{IC}_{50}$ values were found to be $5.3,6.2$, 6.8 and $12 \mu \mathrm{g} \mathrm{mL}^{-1}$ respectively for methanol, aqueous methanol and water extracts of A. polystachya and Vitamin C. 


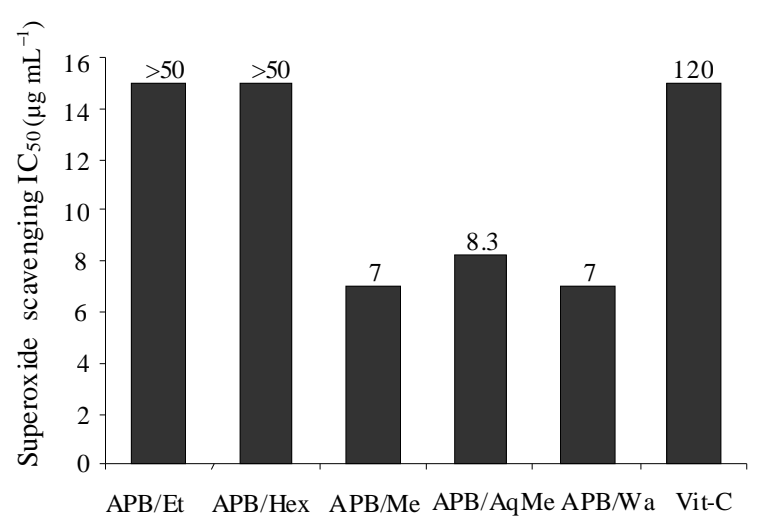

Fig. 1: Superoxide free radical scavenging activity of A. polystachya extracts

Note: Bar diagrammatic representations of in vitro superoxide radical scavenging activity. The bars represent, A. polystachya bark hexane, ethylacetate, methanol, aqueous methanol and water extracts and a positive control Vitamin C. Each bar represents 50\% inhibitory concentration ( $\mathrm{IC}_{50}$ in $\mu \mathrm{g} \mathrm{mL}^{-1}$ )

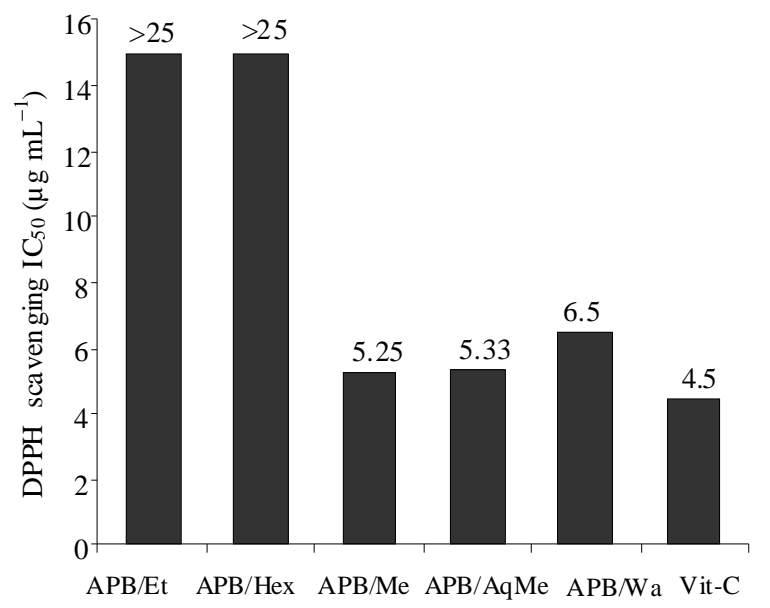

Fig. 2: DPPH free radical scavenging activity of A. polystachya extracts

Note: Bar diagrammatic representations of in vitro DPPH radical scavenging activity. The bars represent, A. polystachya bark hexane, ethylacetate, methanol, aqueous methanol and water extracts and a positive control Vitamin C. Each bar represents $50 \%$ inhibitory concentration $\left(\mathrm{IC}_{50}\right.$ in $\mu \mathrm{g} \mathrm{mL}^{-1}$ )

FRAP assay: A. polystachya bark extracts exhibited superior ferric reducing antioxidant power as depicted in Fig. 4, compared to that of vitamin C. The $\mathrm{EC}_{1}$ values indicated that the ferric reducing antioxidant potential of methanol extract was about 2 fold higher compared to vitamin $\mathrm{C}$. The FRAP $\mathrm{EC}_{1}$ values were found to be 12.8, 18.6, 20.4 and $>25 \mu \mathrm{g} \mathrm{mL}$ respectively, for methanol, aqueous methanol and water extracts of A. polystachya and Vitamin C.

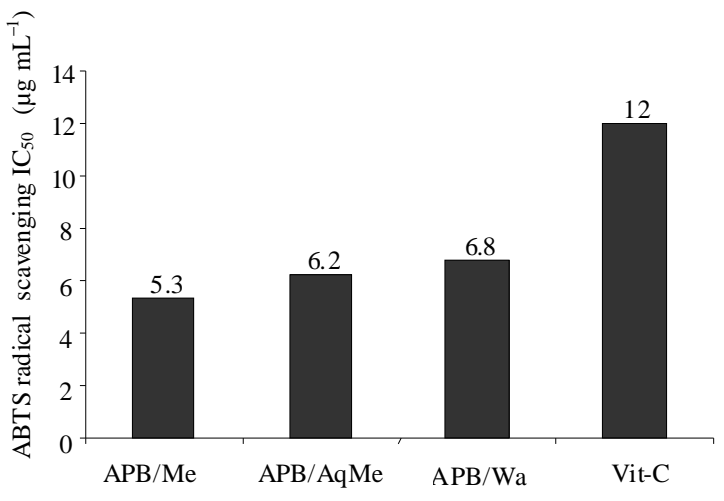

Fig. 3: ABTS free radical scavenging activity of A. polystachya extracts

Note: Bar diagrammatic representations of in vitro ABTS radical scavenging activity. The bars represent, A. polystachya bark methanol, aqueous methanol and water extracts and a positive control Vitamin C. Each bar represents $50 \%$ inhibitory concentration $\left(\mathrm{IC}_{50}\right.$ in $\mu \mathrm{g} \mathrm{mL}^{-1}$ )

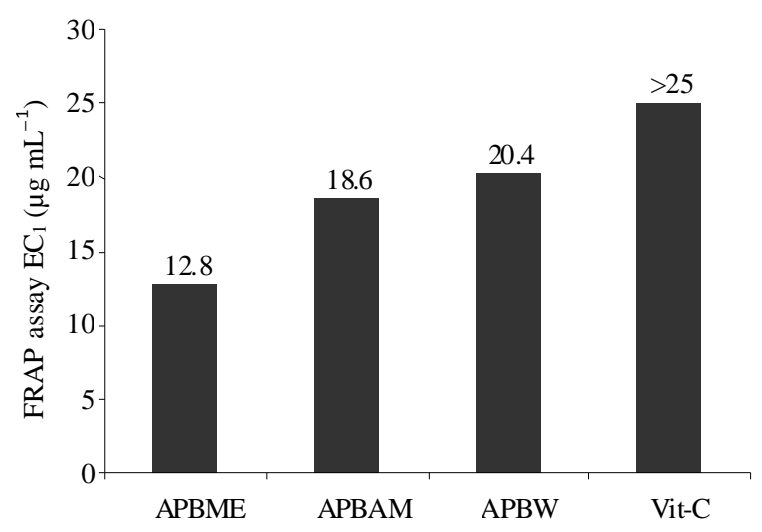

Fig. 4: Ferric reducing antioxidant power of $A$. polystachya extracts

Note: Bar diagrammatic representations of in vitro Ferric Reducing Antioxidant Potential (FRAP). The bars represent, $A$. polystachya bark methanol, aqueous methanol and water extracts and a positive control Vitamin C. Each bar represents concentration of antioxidant required to reduce $1 \mu \mathrm{M}$ of Ferric ions $\left(\mathrm{EC}_{1}\right.$ in $\left.\mu \mathrm{g} \mathrm{mL}^{-1}\right)$

\section{In Vivo Antioxidant activity:}

Effect of AP 110/82C on hepatic lipid peroxidation: Oral supplementation of AP 110/82C at a daily dose of 50 and $100 \mathrm{mg} \mathrm{kg}^{-1}$ body weight for 28 days exhibited significant reduction in hepatic MDA levels compared to that of disease control group. Figure 5 shows that both doses (50 and $100 \mathrm{mg} \mathrm{kg}$ ) of AP 110/82C exhibited statistically significant inhibition of hepatic lipid peroxidation to $(320.64 \pm 20.9$ and $269.28 \pm 48.26 \mathrm{nM} \mathrm{mg}^{-1}$ protein) compared to the control group at $373.69 \pm 3.87 \mathrm{nM} \mathrm{mg}^{-1}$ protein). 


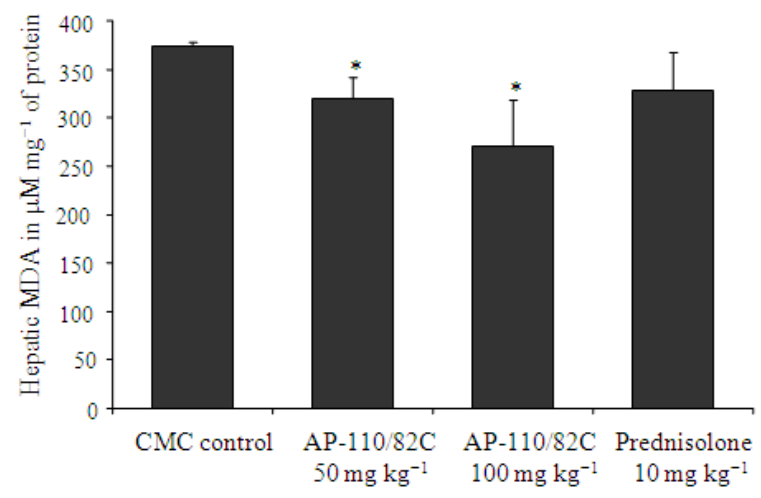

Fig. 5: Effect of A. polystachya fraction (AP-110/82C) on Hepatic MDA level

Note: Bar diagrammatic representations of hepatic MDA concentrations in different group of animals. After 14 days of FCA challenge. The bars represent, control, AP 110/82 C $50 \mathrm{mg} \mathrm{kg}^{-1} ; 100 \mathrm{mg} \mathrm{kg}^{-1}$ and prednisolone $10 \mathrm{mg} \mathrm{kg}^{-1}$. Each bar represents mean \pm SEM. $N=6, *: p<0.05$

Positive control, prednisolone $\left(328.76 \pm 38.87 \mathrm{nM} \mathrm{mg}^{-1}\right.$ of protein) did not exhibit significant reduction in hepatic MDA compared to control.

Effect of AP 110/82C on total hepatic glutathione: A dose dependent increase in the level of total hepatic glutathione was observed in the AP 110/82C (50 and $100 \mathrm{mg} \mathrm{kg}^{-1}$ body weight) supplemented groups when compared to the disease control group. The increase in hepatic glutathione level $(6.93 \pm 1.11$ and $17.05 \pm 2.93 \mu \mathrm{g} \mathrm{mg}^{-1}$ protein) treated with $100 \mathrm{mg} \mathrm{kg}^{-1}$ of AP 110/82C was remarkably higher compared to the control group $\left(5.78 \pm 2.30 \mu \mathrm{g} \mathrm{mg} \mathrm{m}^{-1}\right.$ protein). The $100 \mathrm{mg} \mathrm{kg}^{-1}$ AP 110/82C treated group and $10 \mathrm{mg} \mathrm{kg}^{-1}$ prednisolone $\left(13.6 \pm 2.30 \mu \mathrm{g} \mathrm{mg}^{-1}\right.$ protein) treated group exhibited statistically significant improvement of hepatic glutathione levels compared to control.

Effect of AP 110/82C on total hepatic catalase levels: A dose dependent increase in the level of total hepatic catalase was observed in both the AP 110/82C (50 and $100 \mathrm{mg} \mathrm{kg}^{-1}$ body weight) supplemented groups when compared to the disease control. The increase in hepatic catalase levels $\left(668.95 \pm 75.69\right.$ and $777.02 \pm 82.15 \mu \mathrm{g} \mathrm{mg}^{-1}$ protein) in 50 and $100 \mathrm{mg} \mathrm{kg}^{-1}$ AP $110 / 82 \mathrm{C}$ treated groups were remarkably higher than that in the control group (510.0 $\pm 1.092 \mu \mathrm{g} \mathrm{mg}^{-1}$ protein), however only high dose treated group exhibited statistically significant efficacy in improving hepatic catalse levels compared to those of control and $10 \mathrm{mg} \mathrm{kg}{ }^{-1}$ prednisolone $\left(510.0 \pm 1.092 \mu \mathrm{g} \mathrm{mg}^{-1}\right.$ protein) treated groups.

\section{DISCUSSION}

A. polystachya extracts exhibited potent in vitro antioxidant activity in superoxide free radical scavenging assay (NBT method), DPPH-radical scavenging assay; ABTS free radical scavenging activity and FRAP assay, in comparison to the known antioxidants, such as vitamin C.

Superoxide anion is an oxygen-centered radical with selective reactivity. This species is produced by a number of enzyme systems in auto-oxidation reactions and by nonenzymatic electron transfers that univalently reduce molecular oxygen. It can also reduce certain iron complexes such as cytochrome ${ }^{[30]}$. The present study showed potent superoxide radical scavenging activity for A. polystachya bark extracts (Fig. 1). Methanol and aqueous methanol extracts showed potent Superoxide radical scavenging activity with $\mathrm{IC}_{50}$ values 7 and $7 \mu \mathrm{g} \mathrm{mL}^{-1}$ respectively, compared to other A. polystachya bark extracts and Vitamin C $\left(125 \mu \mathrm{g} \mathrm{mL}^{-1}\right)$.

The DPPH test provided information on the reactivity of test compounds with a stable free radical. Because of its odd electron, 2, 2-Diphenyl-Picryl Hydrazyl radical (DPPH) gives a strong absorption band at $517 \mathrm{~nm}$ in visible spectroscopy (deep violet color). The efficacies of anti-oxidants are often associated with their ability to scavenge stable free radicals ${ }^{[31]}$. In the present study, (Fig. 2), methanol and aqueous methanol extracts exhibited comparable DPPH radical scavenging activity with $\mathrm{IC}_{50}$ values 5.25 and 5.33 respectively compared to vitamin $\mathrm{C}\left(\mathrm{IC}_{50} 4.5 \mu \mathrm{g} \mathrm{mL}^{-1}\right)$.

The decolorization of $\mathrm{ABTS}^{++}$cation radical is an unambiguous way to measure the antioxidant activity of phenolic compounds. Recently, Awika et al. ${ }^{[32]}$ found positive correlations between phenolic content and antioxidant activity tested using the Oxygen Radical Absorbance Capacity (ORAC), ABTS and the 1,1Diphenyl-2-Picrylhydrazyl (DPPH) assays. Thus the ability of a compound to scavenge $\mathrm{ABTS}^{\circ+}$ radical can demonstrate oxygen radical absorbance capacity. Results of the present study revealed that methanol and aqueous methanol extracts possesses superior antioxidant activities (Fig. 3). Methanol and aqueous methanol extracts of A. polystachya showed very potent ABTS radical scavenging activity $\left(\mathrm{IC}_{50} 5.3\right.$ and $\left.6.2 \mu \mathrm{g} \mathrm{mL}^{-1}\right)$ compared to Vitamin $\mathrm{C}\left(12.0 \mu \mathrm{g} \mathrm{mL}^{-1}\right)$.

FRAP assay measures the reducing ability of antioxidants against oxidative effects of reactive oxygen species. Electron donating anti-oxidants can be described as reductants and inactivation of oxidants by reductants can be described as redox reactions. Total antioxidant power may be referred analogously to total 
reducing power. In the current study methanol and aqueous methanol extracts of $A$. polystachya exhibited about 2 folds greater antioxidant power with $\mathrm{EC}_{1}$ values 12.8 and $18.6 \mu \mathrm{g} \mathrm{mL}^{-1}$ respectively when compared to Vitamin $\mathrm{C}$ having $\mathrm{EC}_{1}>25 \mu \mathrm{g} \mathrm{mL}{ }^{-1}$.

MDA is the major oxidation product of peroxidized poly-unsaturated fatty acids and the increased MDA content is an important indicator of lipid peroxidation ${ }^{[33]}$. Liver is the main detoxifying organ in the body and as such it possesses a high metabolic rate and it is subjected to many insults potentially causing oxidative stress. Hence, a corrective measure to stabilize the hepatic antioxidant defense system is of paramount importance for the maintenance of health ${ }^{[34]}$. The present study was undertaken to assess the effect of oral administration of AP 110/82C an active fraction obtained from a mixture of methanol and aqueous methanol extracts, on the in vivo antioxidant status through the estimation of MDA concentration in the liver of rats (Fig. 5).

The hepatic MDA content animals subjected to FCA-induced oxidative stress was found to be significantly increased. This enhanced oxidative stress however was significantly $(\mathrm{p}<0.05)$ reduced in both the treatment groups. AP 110/82C showed dose dependent (320.6 and $269.3 \mu \mathrm{M} \mathrm{mg}^{-1}$ protein respectively for 50 and $100 \mathrm{mg} \mathrm{kg}^{-1}$ ) and statistically significant inhibition of lipid peroxidation as shown by the reduction in hepatic MDA level and the efficacy was found to be better than predinisolone at $10 \mathrm{mg} \mathrm{kg}^{-1}$ dose.

Glutathione, a major non-protein thiol in living organisms, plays a central role in coordinating the body's antioxidant defense processes. Excessive peroxidation causes increased glutathione consumption. Reduced thiols have long been reported to be essential for recycling of antioxidants like vitamin $\mathrm{E}$ and vitamin $\mathrm{C}^{[35]}$. Administration of thiol compounds such as glutathione, cysteine and methionine have been shown to protect against oxidative stress in humans and animals. The liver tissue glutathione levels were significantly depleted in the placebo treated control group after inducing the oxidative stress with FCA. The tissue glutathione levels, however, were significantly elevated in the groups supplemented with AP 110/82C. Treatment with AP $110 / 82 \mathrm{C}$ resulted in significant $(\mathrm{p}<0.05)$ increase in hepatic glutathione levels compared to that of FCA-induced oxidative stress rats. Therefore, it clearly demonstrates that AP 110/82C have protective role against oxidative damage in the liver tissue. Hepatic glutathione status exhibited by AP $110 / 82 \mathrm{C}$ at $100 \mathrm{mg} \mathrm{kg}^{-1}$ body weight was better than that obtained by prednisolone $10 \mathrm{mg} \mathrm{kg}^{-1}$ treated group, as shown in Fig. 6.

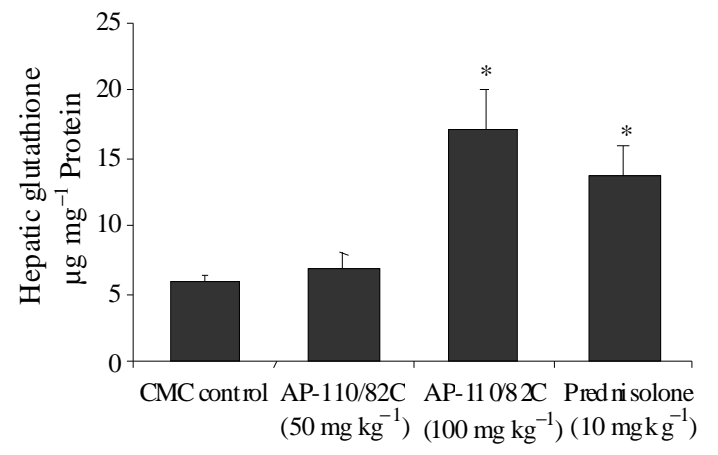

Fig. 6: Effect of A. polystachya fraction (AP-110/82C) on Hepatic glutathione level

Note: Bar diagrammatic representations of hepatic glutathione concentrations in different group of animals. After 14 days of FCA challenge. The bars represent, control, AP 110/82 C $50100 \mathrm{mg} \mathrm{kg}^{-1}$ and prednisolone $10 \mathrm{mg} \mathrm{kg}^{-1}$. Each bar represents mean \pm SEM. $\mathrm{N}=6, *: \mathrm{p}<0.05$

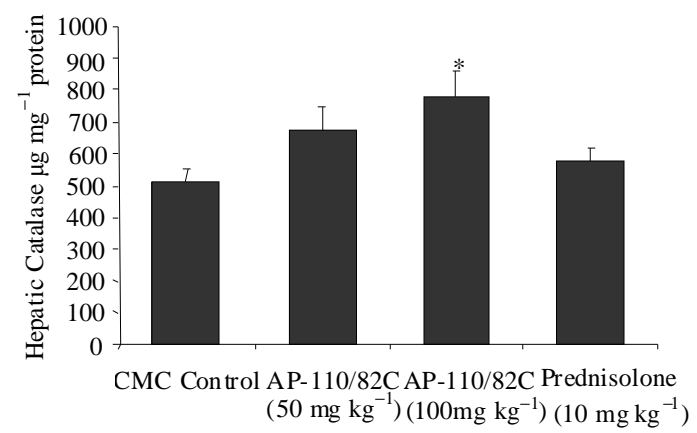

Fig. 7: Effect of A. polystachya fraction (AP-110/82C) on Hepatic catalase level

Note: Bar diagrammatic representations of hepatic catalase concentrations in different group of animals. After 14 days of FCA challenge. The bars represent, control, AP 110/82 C $50 ; 100 \mathrm{mg} \mathrm{kg}^{-1}$ and prednisolone $10 \mathrm{mg} \mathrm{kg}^{-1}$. Each bar represents mean \pm SEM. $N=6, *: p<0.05$

Catalase is an enzymatic antioxidant widely distributed in all animal tissues including $\mathrm{RBC}$ and liver. Catalase decomposes hydrogen peroxide and helps protect the tissues from highly reactive hydroxyl radicals ${ }^{[36]}$. AP 110/82C supplementation resulted in dose dependent and significant improvement in hepatic catalase levels. Both doses (50 and $100 \mathrm{mg} \mathrm{kg}^{-1}$ ) of AP $110 / 82 \mathrm{C}$ exhibited better improvement in hepatic catalase levels compared to prednisolone $10 \mathrm{mg} \mathrm{kg}^{-1}$ treated group, as shown in Fig. 7.

\section{CONCLUSION}

In the present investigation, we evaluated comparative antioxidant activity of various 
A. polystachya extracts in comparison to Vitamin C. Methanol and aqueous methanol extracts exhibited up to 3 fold better efficacy in various in vitro antioxidant assays. These in vitro results are supported by in vivo data. Rats supplemented with 50 and $100 \mathrm{mg} \mathrm{kg}^{-1}$ of AP 110/82C resulted in dose dependent and significant improvement in oxidative status, as indicated by significant reduction in hepatic lipidperoxidation with simultaneous elevation in hepatic glutathione and catalase levels. These antioxidant studies proved superior efficacy of A. polystachya extracts and the potent fraction AP $110 / 82$ C. As AP $110 / 82 C$ is of natural origin, it is a safe and effective intervention for free radical mediated diseases.

\section{ACKNOWLEDGEMENT}

The researchers thank Sri G. Ganga Raju, Chairman, Mr G. Rama Raju, Director Laila Group and Mr Kiran CEO, Laila Nutraceuticals for encouragement and support. The researchers thank Dr. Krishanu Sengupta for technical support in evaluating hepatic antioxidant status.

\section{REFERENCES}

1. Allen, L.H., 2003. Mechanisms of pathogenesis: Evasion of killing by polymorphonuclear leukocytes. Microbes Infect., 5: 1329-1335. DOI: 10.1016/j.micinf.2003.09.011

2. Grimble, R.F., 1994. Nutritional anti-oxidants and the modulation of inflammation: Theory and practice. New Horiz., 2: 175-185. http://www.ncbi.nlm.nih.gov/pubmed/7922442

3. Halliwell, B., 1997. Antioxidants and human diseases: A general introduction. Nutr. Rev., 55: 44-52. http://www.ilsi.org/

4. Pietta, P.G., 2000. Flavonoids as antioxidant. J. Nat. Prod., 63: 1035-1042. DOI: 10.1021/np9904509

5. Cerutti, P., 1994. Oxy-radicals and cancer. Lancet, 344: 862-863. DOI: 10.1016/S0140-6736(94)92832-0

6. Ames, B.N., L.S. Gold and W.C. Willet, 1995. The causes and prevention of cancer. Proc. Natl. Acad. Sci. USA., 92: 5258-5265.

http://www.pubmedcentral.nih.gov/articlerender.fc gi? artid $=41674$

7. Sheng, M.S., S.Y. Tay and C.P. Jung, 2008. Antioxidant activities of citrus herbal product extracts. Food Chem., 111: 892-896. DOI: 10.1016/j.foodchem

8. Iqbal, M., Y. Okazaki and S. Okada, 2009. Curcumin attenuates oxidative damage in animals treated with a renal carcinogen, Ferric Nitrilotriacetate (Fe-NTA): Implications for cancer prevention. Mol. Cell. Biochem., DOI: 10.1007/s11010-008-9994-Z
9. Kiselova, Y., I. Diana, C. Trifon, G. Daniela, G. Bistra and Y. Tatyana, 2006. Correlation between the in Vitro antioxidant activity and polyphenol content of aqueous extracts from bulgarian herbs. 20: 961-965. DOI: $10.1002 / \mathrm{ptr}$

10. Chopra, R.N., S.L. Nayar and I.C. Chopra, 1956. Glossary of Indian Medicinal Plants. CSIR, New Delhi, pp: 330.

11. Graham, J.G., M.L. Quinn, D.S. Fabricant and N.R. Farnsworth, 2000. Plants used against canceran extension work of Jonathan Hartwell. J. Ethnopharmacol., 73: 347-377. DOI: 10.1016/S0378-8741(00)00341-X

12. Choudhury, R., M.H. Choudhury and M.A. Rashid, 2003. Antimicrobial activity of Toona ciliata and Amoora rohituka. Fitoterapia, 74: 155-158. DOI: 10.1016/S0367-326X(02)00322-2

13. Zhang, H., F. Chen, X. Wang, D. Wu and Q. Chen, 2007. Complete assignments of $1 \mathrm{H}$ and 13C NMR data for rings A,B-seco limonoids from the seed of Aphanamixis polystachya. Magnet. Resonance Chem., 45: 189-92. DOI: 10.1002/mrc

14. Agnihotri, V.K., S.D. Srivastava and S.K. Srivastava, 1987. A new limonoid, amoorinin, from the stem bark of Amoora rohituka. Planta Med., 53: 298-299. http://www.thiemeconnect.com/ejournals/pdf/plantamedica/doi/10.10 55/s-2006-962715.pdf

15. Jain, S.A. and S.K. Srivastava, 1985. 8-C-methylquercetin-3-O-b -Dxylopyranoside, a new flavone glycoside from the roots of Amoora rohituka. J. Nat. Prod., 48: 299-301. DOI: 10.1021/np50038a016

16. Chatterjee, A., A.B. Kundu, T. Chakrabortty and S. Chandrasekharan, 1970. Extractives of Aphanamixis polystachya wall. Structures and stereochemistry of aphanamixin and aphanamixinin. Tetrahedron, 26: 1859-67. DOI: 10.1016/S0040-4020(01)92762-0

17. Choudhury, R., M.H. Choudhury and M.A. Rashid, 2003. Guanine sesquiterpenes from Amoora rohituka. Phytochemistry, 62: 1213-1216. DOI: 10.1016/S0031-9422(02)00698-2

18. Harmon, A.D., U. Weiss and J.V. Silverton, 1979. The structure of rohitukine, the main alkaloid of Amoora rohituka (Syn. Aphanamixis polystachya) (Maliaceae). Tetrahedron Lett., 20: 721-724. DOI: 10.1016/S0040-4039(01)93556-7

19. Graham, J.G., M.L. Quinn, D.S. Fabricant and N.R. Farnsworth, 2000. Plants used against canceran extension of the work of Jonathan Hartwell. J. Ethnopharmacol., 73: 347-377. DOI: 10.1016/S0378-8741(00)00341-X 
20. Jagetia, G.C. and V.A. Venkatesh, 2006. Treatment of mice with stem bark extract of Aphanamixis polystachya reduces radiation-induced chromosome damage. Int. J. Radiat. Biol., 82: 197-209. DOI: 10.1080/09553000600621413

21. Chowdhury, R. and R.B. Rashid, 2003. Effect of the crude extracts of Amoora rohituka stem bark on gastrointestinal transit in mice. Indian $\mathrm{J}$. Pharmacol., 35: 304-307. http://cat.inist.fr/?aModele $=$ afficheN\&cpsidt $=1524$ 0773

22. Talukder, F.A. and P.E. Howse, 1995. Evaluation of Aphanamixis polystachya as a source of repellents, antifeedants, toxicants and protectants in storage against Tribolium castaneum (Herbst). J. Stored Prod. Res., 31: 55-61. DOI: 10.1016/0022474X(94)00036-S

23. Cord, M.J.M. and I. Fridovich, 1969. Superoxide dismutase: An enzymatic function for erythrocuperin. J. Biol. Chem., 244: 6049-6055. http://www.jbc.org/cgi/content/abstract/244/22/6049

24. Szabo, M.R., C. Iditoiu, D. Chambre and A.X. Lupea, 2007. Improved DPPH determination for antioxidant activity spectrophotometric assay. Chem. Pap., 61: 214-216. DOI: 10.2478/s11696007-0022-7

25. Roberta, R., N. Pellegrini, A. Proteggente, A. Pannala, M. Yang and C. Rice-Evans, 1999. Antioxidant activity applying an improved ABTS radical cation de-coloration assay. Free radical Biol. Med., 26: 1231-1237. DOI: 10.1016/S08915849(98)00315-3

26. Benzie, I.F. and J.J. Strain, 1996. The Ferric Reducing Ability of Plasma (FRAP) as a measure of antioxidant power. The FRAP assay. Anal. Biochem., 239: 70-76. DOI: 10.1006/abio.1996.0292

27. Ohkawa, H., N. Ohishi and K. Yagi, 1979. Assay for lipid peroxide in animal tissues by thiobarbituric acid reaction. Anal. Biochem., 95: 351-358.

http://www.ncbi.nlm.nih.gov/pubmed/36810
28. Grunert, R.R. and P.H. Phillips, 1951. A modification of nitroprusside method of analysis for glutathione. Arch. Biochem., 30: 217-225. http://www.ncbi.nlm.nih.gov/pubmed/14811490

29. Johansson, L.H. and L.A.H. Borg, 1988. A spectrophotometric method for determination of catalase activity in small tissue samples. Anal. Biochem., 174: 331-336. DOI: 10.1016/00032697(88)90554-4

30. Gulcin, L., H.A. Alici and M. Cesur, 2005. Determination of in vitro antioxidant and radical scavenging activities of propofol Chem. Pharm. Bull., 53: 281-285. DOI: 10.1248/cpb.53.281

31 Wang, M., Y. Jin and C.T. Ho, 1999. Evaluation of resveratrol derivatives as potential antioxidants and identification of a reaction product of resveratrol and 2, 2-diphenyl-1-picryhydrazyl radical. J. Agric. Food Chem., 47: 3974-3977. DOI: 10.1021/jf990382w

32. Awika, J.M., L.M. Rooney, X. Wu, R.L. Prior and L.C. Zevallos, 2003. Screening methods to measure antioxidant activity of sorghum (Sorghum bicolor) and sorghum products. J. Agric. Food Chem., 51: 6657-6662. DOI: 10.1021/jf034790i

33. Halliwell, B. and S. Chirico, 1993. Lipid peroxidation: Its mechanism, measurement and significance. Am. J. Clin. Nutr., 57: 715S-724S. http://www.ajcn.org/cgi/reprint/57/5/715S

34. Alia, M., C. Horcajo, L. Bravo and L. Goya, 2003. Effect of grape antioxidant dietary fiber on the total antioxidant capacity and the activity of liver antioxidant enzymes in rats. Nutr. Res., 23: 1251-1267. DOI: 10.1016/S0271-5317(03)00131-3

35. Constantinescu, A., D. Han and L. Packer, 1993. Vitamin $\mathrm{E}$ recycling in human erythrocyte membrane. J. Biol. Chem., 268: 10906-10913. http://www.jbc.org/cgi/reprint/268/15/10906

36. Chance, B. and D.S. Greenstein, 1992. The mechanism of catalase actions-steady state analysis. Arch. Biochem. Biophys., 37: 301-339. 